\title{
Nest Structure of the Neotropical Social Wasp Mischocyttarus baconi (Hymenoptera: Vespidae)
}

by

\author{
Andrea A. Scobie ${ }^{1} \&$ Christopher K. Starr ${ }^{2}$
}

\begin{abstract}
The uncovered, single-comb nests of Mischocyttarus baconiStarr have short, stout, centric petioles. We describe nest size, cell size, petiole dimensions, and the position of the petiole. In a sample of 91 nests, the comb comprised up to 198 cells. Cells had a mean side-to-side diameter at the mouth of 3.4 $\mathrm{mm}$. The petiole had a mean length of 2.9 and a modal width of $2.0 \mathrm{~mm}$. The degree of excentricity was determined for a sample of nests of at least 20 cells. As expected, those attached to vertical substrates (wall nests) showed greater excentricity than those attached to horizontal substrates (ceiling nests).

\section{INTRODUCTION}

Mischocyttarus is a genus of about 250 known species of independentfounding social wasps restricted to the New World (Silveira 2008). In common with other independent-founding polistines, Mischocyttarus nests typically each consist of a single uncovered comb of cells (Gadagkar 1991). Mischocyttarus baconi Starr is found throughout the island of Trinidad, West Indies, where it often nests in and on buildings. The wasps very closely resemble the sympatric M. alfkenii (Ducke), but the two build distinct nests (O'Connor et al 2011). That of M. baconi is made of darker carton with the petiole attached at or near the middle of the comb (centric), while that of M. alfkenii is of lighter carton with the petiole attached at one edge of the comb (excentric).

Silveira (2008) places M. alfkenii (and by implication M. baconi) in a species group with seven other species within the subgenus Phi. Richards's (1978) brief notes on nest form indicate that centric-petiole and excentric-petiole nests are each typical of several species in this species-group.

Dep't of Life Sciences, Univ. of the West Indies, St Augustine, Trinidad \& Tobago

${ }^{1}$ Present address: Dep't of Biology, Univ. of the Southern Caribbean, Maracas St Joseph, Trinidad \& Tobago; an8scobie@yahoo.com

${ }^{2}$ ckstarr@gmail.com 


\section{MATERIALS AND METHODS}

Our core study locality was the University of the West Indies campus at

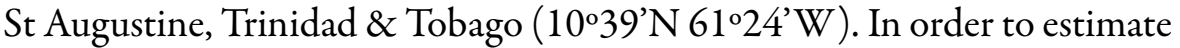
the frequency distribution of final nest size, we collected all abandoned $M$. baconi nests from under concrete eaves of a large building at the core locality. Our descriptive notes from these are supplemented by 28 active nests and from abandoned nests from other sites nearby. Most nests were attached to either a horizontal (henceforth "ceiling") or a vertical (henceforth "wall") surface. Before removal, we marked the tops of wall nests.

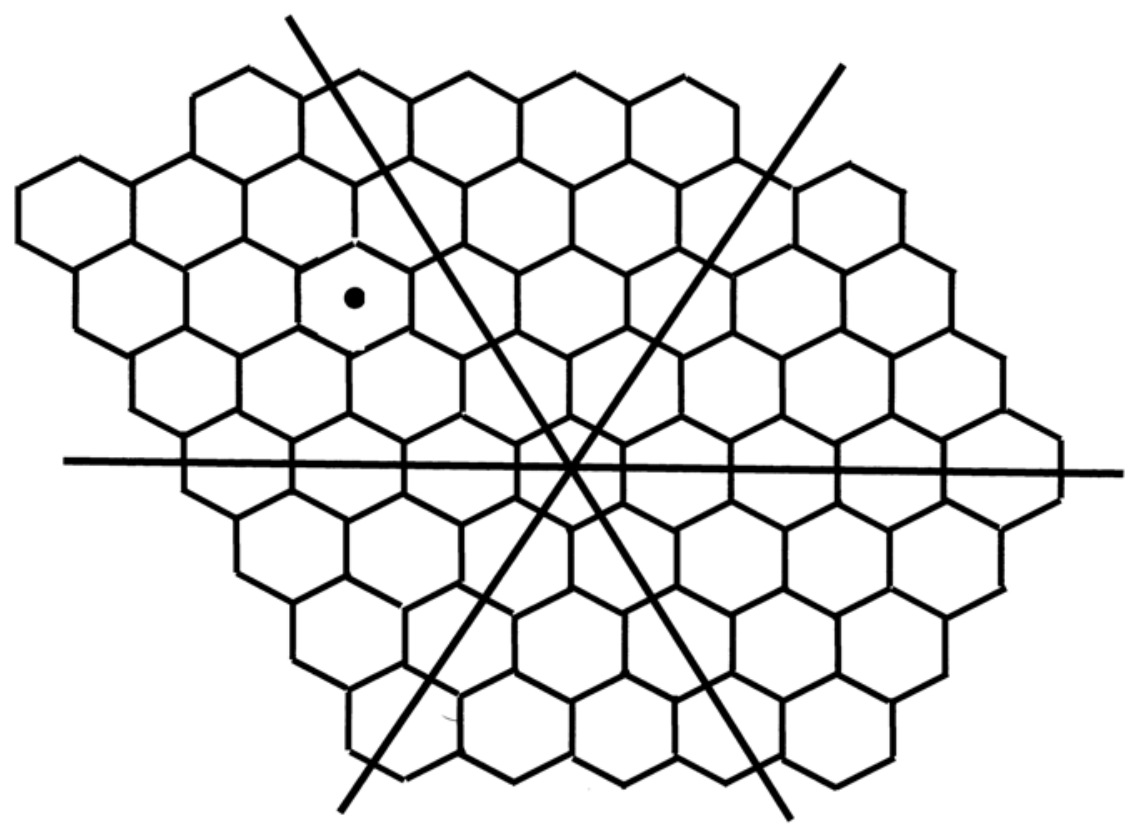

Fig. 1. Map of nest Z to illustrate calculation of mean side-to-side cell diameter and degree of excentricity. In this example, mean cell diameter is the summed length of the three lines (from edge to edge of the nest) divided by 23 . Intersecting diameter lines show the center, while $\bullet$ marks the position of the petiole. Excentricity is the ratio of the distance (in cell diameters) between the center and the petiole to the distance between the center and the edge cell. Where the petiole is not on a midline cell, we place it on the nearest cell wall or cell center along a midline in order to calculate excentricity. In nest $Z$, excentricity $=2.5 / 4=0.625$. 
In a sample of eight nests, we measured the width of the comb along three midlines (Fig. 1). These figures were then used to calculate mean side-to-side cell diameter.

We determined the degree of excentricity of all larger $(\geq 20$ cells $)$ ceiling and wall nests according to two indices, in each of which a nest with the petiole attached to a peripheral cell has maximum excentricity: a) that of Karsai \& Pénzes (1996), and b) a simpler alternative (Fig. 1).

\section{RESULTS AND DISCUSSION}

M. baconi builds a nest of medium-brown carton. The comb is usually very roughly circular and lies approximately parallel to the substrate, where this is flat.

Fig. 2 shows the array of nest sizes in our sample of 91 abandoned nests from the core locality. These had a range of 1-198 cells, with a median of 12 and mean of 26.5. The overall pattern, then, is of a large fraction of very small nests (most of which presumably failed without producing adult brood) and a smaller fraction of relatively large, successful nests.

In measuring cell widths of eight nests, we found that one nest had unusually narrow cells. The mean cell width of the other seven nests was $3.4 \mathrm{~mm}$.

The petiole had a modal length of $3 \mathrm{~mm}$ (Table 1). Petiole width was variable, and often irregular within individual petioles. Estimates to the nearest half-millimeter gave a modal width of $2 \mathrm{~mm}$.

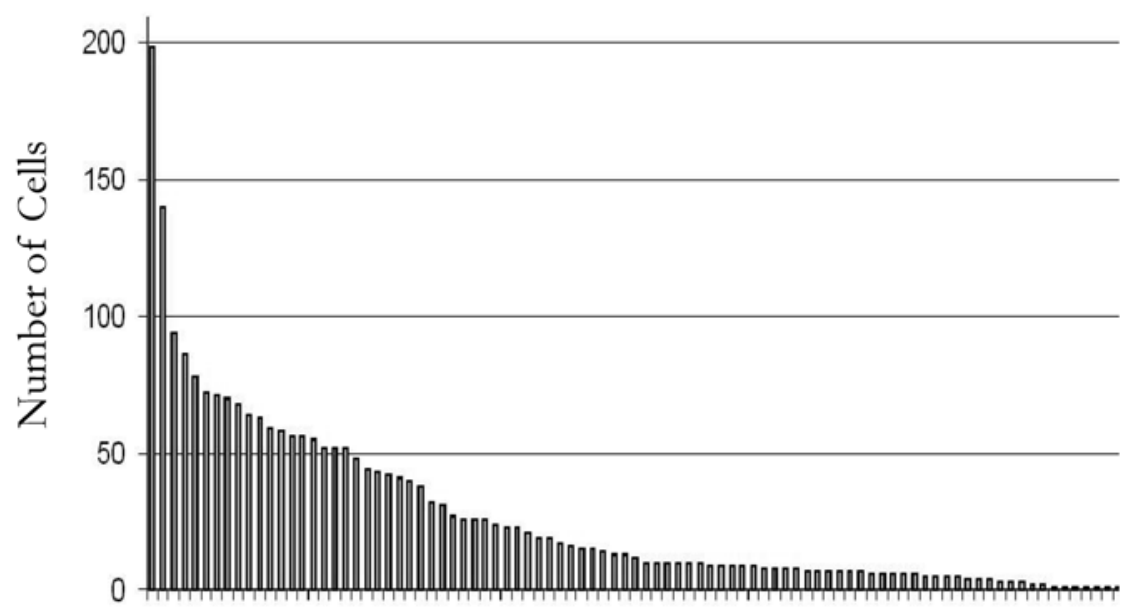

Fig. 2. Size (number of cells) of 91 Mischocyttarus baconi nests in descending order. 
Of 95 nests under concrete eaves at the core locality, 29 (31\%) were attached to ceilings and 66 (69\%) to walls, although both types of surface were abundantly available, and each nest had room to expand on all sides. The degree of excentricity, according to the index shown in Fig. 1, of the 29 larger nests is shown in Table 1. The data show substantially greater excentricity in wall nests. Furthermore, fully centric nests (excenticity $=0$ ) were found only on ceilings, and fully excentric nests (excentricity $=1$ ) were found only on walls. In particular, combs from both types of nests tended to be roughly circular to about the same degree. In all wall nests, the petiole was higher than the comb center, although often not directly above the center. Aside from the attachment position of the petiole, wall and ceiling nests showed one grossstructural difference: The cells of wall nests tended to open slightly downward, not perpendicular to the substrate.

In gross structure, the nest of M. baconi resembles those of some other members of its species-group and subgenus.

Fig. 2 shows the size-frequency distribution of abandoned nests, consistent with the hypothesis of a very high failure rate early in the colony cycle, followed by a time of lower risk.

The results show a distinct preference for walls over ceilings as a

Table 1. Structural parameters of 26 nests of Mischocyttarus baconi. A ceiling nest is attached below a horizontal substrate, while a wall nest is attached to a vertical substrate. Comb excentricity, with a value between 0 and 1 , is according to an index described in the text and illustrated in Fig. 1.

\begin{tabular}{|c|c|c|c|}
\hline $\begin{array}{l}\text { Nest } \\
\text { no. }\end{array}$ & $\begin{array}{l}\text { Number } \\
\text { of cells }\end{array}$ & $\begin{array}{l}\text { Petiole } \\
\text { length (mm) }\end{array}$ & Excentricity \\
\hline \multicolumn{4}{|c|}{ Ceiling nests $n=11$} \\
\hline a & 22 & 4 & 0.33 \\
\hline $\mathrm{J}$ & 24 & 3 & 0.67 \\
\hline c & 35 & & 0.25 \\
\hline $\mathrm{O}$ & 42 & 2 & 0.25 \\
\hline B2 & 52 & 2 & 0.33 \\
\hline b & 53 & & 0.38 \\
\hline $\mathrm{C} 2$ & 63 & 1 & 0.25 \\
\hline D2 & 64 & & 0 \\
\hline $\mathrm{Y} 2$ & 68 & 3 & 0 \\
\hline $\mathrm{P}$ & 72 & 3 & 0.20 \\
\hline $\mathrm{Z} 2$ & 94 & 3.5 & 0.30 \\
\hline Mean & 53.5 & 2.7 & 0.27 \\
\hline \multicolumn{4}{|c|}{ Wall nests $n=19$} \\
\hline P2 & 21 & 2 & 1 \\
\hline $\mathrm{N} 2$ & 23 & & 1 \\
\hline W & 23 & 3 & 0.50 \\
\hline $\mathrm{K}$ & 26 & & 0.50 \\
\hline $\mathrm{X} 2$ & 27 & & 0.67 \\
\hline $\mathrm{Y}$ & 38 & 4 & 1 \\
\hline $\mathrm{L}$ & 40 & 3 & 0.67 \\
\hline V2 & 43 & 3 & 0.67 \\
\hline $\mathrm{N}$ & 45 & 2 & 0.67 \\
\hline A3 & 48 & 4 & 0.25 \\
\hline $\mathrm{X}$ & 50 & 3 & 0.25 \\
\hline M & 52 & 2 & 0.67 \\
\hline Z & 55 & 2 & 0.63 \\
\hline $\mathrm{R}$ & 56 & 2 & 1 \\
\hline R2 & 59 & 3 & 0.63 \\
\hline Q & 70 & 3 & 0.50 \\
\hline U2 & 86 & 4 & 0.50 \\
\hline S2 & 140 & 5 & 0.27 \\
\hline $\mathrm{T} 2$ & 198 & 4 & 0.36 \\
\hline Mean & 57.9 & 3.1 & 0.62 \\
\hline
\end{tabular}


nesting surface. In our experience, most independent-founding polistines that commonly nest on or in buildings much prefer horizontal or near-horizontal surfaces. It is not plain why $M$. baconi should tend to prefer walls or why most other species appear to prefer ceilings.

The greater mean excentricity of walls nests evidently arises through a simple tendency to add new cells on the lower part of the perimeter. This would appear to make good mechanical sense, as a measure of excentricity in wall nests is expected to confer some stability against the shearing force of the nest's weight. For much the same reason, centricity is expected in ceiling nests if the comb is parallel to the surface.

\section{ACKNOWLEDGMENTS}

The main part of this paper is drawn from the first author's MPhil thesis at the University of the West Indies. We thank István Karsai and John Wenzel for discussion and Lee-Ann Beddoe for graphic assistance.

\section{REFERENCES}

Gadagkar, R. 1991. Belonogaster, Mischocyttarus, Parapolybia and independent-founding Ropalidia. Pp. 149-190, In: Ross, K.W. \& R.W. Matthews (eds.), The Social Biology of Wasps. Ithaca: Cornell Univ. Press.

Karsai, S. \&Z. Pénzes 1996. Intraspecific variation in the comb structure of Polistes dominulus: parameters, maturation, nest size and cell arrangement. Insectes Sociaux 43:277-296.

O'Connor, T., C.K. Starr \& S.A. Cameron 2011. The neotropical social wasp Mischocyttarus "alfkenii"Ducke(Hymenoptera:Vespidae) is a pair ofethospecies. SystematicEntomology 36:446-452.

Richards, O.W. 1978. The Social Wasps of the Americas, Excluding the Vespinae. London: British Museum (Natural History) $580 \mathrm{pp}$.

Silveira, O.T.2008. Phylogeny of wasps of the genus Mischocyttarus deSaussure(Hymenoptera, Vespidae, Polistinae). Revista Brasileira de Entomologia 52:510-549.

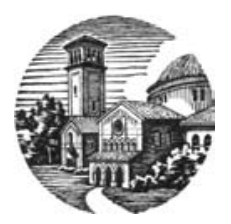


